Egypt. J. of Nutrition and Health Vol. 15 No. 1 January (2020)

\title{
Usage of oil and powder of bottle gourd and pumpkin seeds in production of high nutritive value biscuit
}

\author{
Nahed, M.M. Atta*, Ghada, H.H. Ismaiel ${ }^{\star *}$ and Zein, H. ** \\ ${ }^{*}$ Fats and oils Dept. ** Special Food and Nutrition Dept. \\ Food Technology Research Institute- Agricultural Research Center, Giza, Egypt.
}

\begin{abstract}
This investigation aimed to study the chemical composition of bottle gourd and pumpkin seeds, also to study their physical and chemical properties, fatty acid composition, oxidative stability and bioactive components of oils for the mentioned seeds.Fortified biscuit have been produced by using oil and powder of bottle gourd and pumpkin seeds and determination of physical characteristics, chemical composition and sensory attributes of the produced biscuit comparing with biscuit prepared by using corn oil as control. The results indicated that both bottle gourd and pumpkin seeds are rich in edible oil, protein, fibers and minerals. The extracted oil are rich in omega 6 and 9 have got high oxidative stability and bioactive component. These oils recorded low acidity, peroxide value and $\mathrm{K} 232 \mathrm{~nm}$ and $\mathrm{K} 270 \mathrm{~nm}$ that refers to high quality characteristics of these oils. There was a decrease in linoleic and linolenic acids and an increase in palmitic, stearic and oleic acids of extracted oils from all produced biscuits after baking process compared with them before baking. Fortified biscuit by using oil and powder of bottle gourd and pumpkin seeds contained higher amount of protein, fibers and essential amino acids compared with the biscuit that used corn oil. Prepared biscuit from pumpkin seed powder had the highest acceptance value on sensory evaluation, followed by biscuit prepared by corn oil then biscuit using bottle gourd seed powder, from bottle gourd seed oil and biscuit from pumpkin seed oil.
\end{abstract}

Keywords: Bottle gourd and pumpkin seeds, fatty acids composition, physicochemical characteristic of oils, biscuit preparation and sensory attributes of biscuit.

\section{Introduction}

The calabash, bottle gourd Lagenariasiceraria, is from the family Cucurbitaceae. The genus name legenaria comes from the lagena, the Latin name for Florence flask, referring to the fruit which is useful when it is mature and dry (siccus) (Welman, 2005).Bottle gourd has a wide hemispheric distribution. Remains of $L$. siceraria were identified from Egyptian tombs (dated back to $3000-3500$ B.C), caves of the Thailand (10000 - 6000 B.C) in Mexico (7000 - 5000 B.C), in Peru (4000 - 3000 B.C)B and in China (5000 A.D) (Yetisir et al., 2008). Family Cucurbitaceae, commonly known bottle gourd is considered to be indigenous to various regions of India (Deshpandeet al., 2007). Lagenariasiceraria(Calabash and bottle gourd) belongs to Cucurbitaceae family. The seeds are edible and used in the preparation of local soups, fermented food products (Ogiri), fried cake (robo) and pudding (igbalo or ugbaotiri). The seeds of Lagenariasiceraria are rich in dietary proteins (Fokouet al., 2004). 


\section{Nahed, M.M. Atta et al}

The Cucurbitaceae family includes gourds, melons, pumpkins and squashes. The seeds of many members of the group have been noted for their oil bearing properties, the oil bearing seeds are used to make supplementary food stuffs, thereby making dietary use of the oil(FAO, 1992). Oil seeds of Cucurbitaceae are widely employed in domestic activities and have high nutritive value (Achuet al., 2005). These oil seeds are good sources of lipids and protein with defatted cake capable of being used as a protein supplement in human nutrition (Chinyereet.al., 2009).

Bottle gourd (Lagenariasiceraria) seeds proved to be one of the most important sources containing high content of oil (46.5\%) with high quality characteristics (P.V of $0.31 \mathrm{meq} / \mathrm{kg}$ oil and 0.66 $\%$ FFA) and high oxidative stability, $14.6 \mathrm{hrs}$. at $100^{\circ} \mathrm{C}$ by the Rancimate apparatus. Also, It contained a high amounts of unsaturated fatty acids (63.29\%) represented in $21.55 \%$ oleic, monounsaturated fatty acids and $41.74 \%$ linoleic acid, polyunsaturated fatty acid (Allam, 2010).

The oil yield of bottle gourd seed was $29.33 \%$, the color was dark yellow. The following physic-chemical results were obtained; acid value, 0.47 .01 ; iodine value $123.0312 / 100 \mathrm{gm}$, and saponification value $150 \mathrm{mg} \mathrm{KoH} / \mathrm{g}$. Results of GC-Ms analysis revealed the following fatty acid composition; palmitic acid, stearic acid, eicosadenoic acid, linoleic acid, oleic acid, erucic acid, arachidic acid and behhenic acid. The seed oil contains various phytochemical constituents, polyphenols and antioxidant activity of seed oil of bottle gourd cultivar (Warraet al., 2016).

The pumpkin seed oil is dark green in color and contains high amount of free fatty acids (oleic, linoleic, palmitic and stearic) are present with the relative distribution of $43.89,33.19,13.4$ and $7.8 \%$ respectively, representing $98 \%$ of the total fatty acids amount. The oil content of dry pumpkin seeds is 47.03\%. (Ahmed and Ravi, 2017) also reported that pumpkin seed oil is a nutritional supplements for natural source of proteins, essential fatty acids, polyunsaturated fatty acids, omgea 3,6 and 9, carotenes, lutein, vitamins ( carotenoids, B, $\alpha$-Tocopherols), phytosterols, chlorophyll and trace elements such as zinc and selenium. The oil content of various cucurbit seeds varied from 38 to $60 \%$. The main fatty acids of pumpkin seed oil are linoleic and oleic. Due to its high content of unsaturated fatty acids, it has been suggested as a substitute for highly unsaturated oils in diets (Johnet al., 1997). The moisture content and oil yield of bottle gourd seed ranged from 2.9 to $6.27 \%$ and 18.0 to $32.6 \%$ respectively (Popoolaet al., 2016).

Bakery products such as biscuits are liked by many persons. Several trials were concluded to improve its quality and flavor. (Mona and Amany,2004).Whole or crushed seeds were used in cookies and cheese was added as a flavoring agent in Egypt, India, Turkey Syria and Armenians (Alaa El-Dain et al., 2008). The seed flour of bottle gourd contained adequate essential amino acids which are required by growing school children and adults. The seeds have potential as protein supplement in cereal based complementary diets or in the replacement of animal proteins. The amino acid composition of seed flour of bottle gourd seeds was determined and the protein quality was evaluated by(Ogunbusolaet al., 2010) they are reported that the total essential amino acids ranged from 45.8 to $51.5 \mathrm{mg} / \mathrm{g}$.

The aim of the present study was determine the proximate composition of bottle gourd and pumpkin seeds, physical and chemical properties of extracted oils from these seeds. Also, to study effect of using oil and powder of bottle gourd and pumpkin seeds on the physical properties and sensory attributes of its biscuits. 


\section{Egypt. J. of Nutrition and Health Vol. 15 No. 1 January (2020)}

\section{Materials and Methods}

Materials:

Bottle gourd and pumpkin seeds were obtained from local market in Cairo, Egypt.Soft wheat flour (72\% extraction) was obtained from international co. for processing grain products (Flour land $6^{\text {th }}$ Oct. City, $3^{\text {rd }}$ Industrial Zone, Egypt) and all other materials, sugar ,corn oil, baking powder, eggs and vanilla were obtained from local supermarket in Giza governorate.

Methods:

Oil Extraction from seeds : oil was extracted by cold - press extraction according to the method described by Deli et al., (2011),bottle gourd and pumpkin seed were pressed by screw - press laboratory (model NA21T). With a $5 \mathrm{~mm}$ restrictions die and a screw speed of $20 \mathrm{rpm}$ was used for the $\mathrm{Cp}$ oil expression from seeds. The screw press was first run for $20 \mathrm{~min}$ without seed materials but with heating via an electrical resistance heating ring attached around the press barrel to rise the screw press barrel temperature to the desired temperature $50^{\circ} \mathrm{C}$ monitored by a digital thermometer inserted to the restrictions. The extracted oils were passed over anhydrous sodium sulphate, filtered through whatman no. 1 filter paper,kept in brown bottles at $5^{\circ} \mathrm{C}$ until analysis and use for making biscuits.

\section{Preparation of bottle gourd and pumpkin seeds powder:}

Both of bottle gourd and pumpkin seeds were dehulled manually and milled to fine powder, then sieved on a $100 \mu \mathrm{m}$ sieve. Packed into polyethylene bags and stored in deep freezer $\left(-18^{\circ} \mathrm{C}\right)$ until use in biscuit making.

\section{Mixing process:-}

Soft wheat flour and corn oil which are used to make control biscuit, the basic formula of control biscuits was replaced by using $25.1 \mathrm{gm}$ whole powder from dehulled bottle gourd seed, which contains $11.36 \mathrm{gm}$ oil (on a replacement basic corn oil at level 100\%) plus 13.74gm flour(on a replacement basic soft wheat flour at level $24.2 \%$ ), and also replaced by using $24.59 \mathrm{gm}$ whole powder from dehulled pumpkin seed, which contains $11.36 \mathrm{gm}$ oil(on a replacement basic corn oil at level $100 \%$ ) plus $13.23 \mathrm{gm}$ flour ( on a replacement basic soft wheat flour at level $23.3 \%$ ). In case of mixing bottle gourd and pumpkin seeds oil, corn oil which is used to prepare the basic formula of control biscuits was replaced by bottle gourd and pumpkin seed oil (each one) at level $100 \%$. The added amounts of both bottle gourd and pumpkin powder of dehulled seeds ( 25.1 and $24.59 \%$ respectively) for fortifying biscuit were calculated based on the oil percentage of both the two powders which were 45.42 and $46.2 \%$ respectively.

\section{Preparation of biscuits:-}

Biscuit was prepared according to the method described by Alaa El-Dain et al., (2008)with some modification Table (1).For making biscuits: sugar, oil were created by using a mixing machine for 1 min., eggs were beaten by whip and vanilla was added to the beaten eggs. Sugar oil creamed was added to egg-vanilla mixture and well beaten at low speed for $5 \mathrm{~min}$. dry ingredients (soft wheat flour or its blends and baking powder) were stirred together and added to the mixture gradually followed by continuous beating until the blend become smooth. Then the dough was left to rest for $15 \mathrm{~min}$. The dough was rolled in 3 cookie sheet using a guide roll. The dough was cut in circles $(0.3 \mathrm{~cm}$ thick and 4 $\mathrm{cm}$ diameter). Transferred to greased plate, then baking process was carried out in electrically heat oven at $170^{\circ} \mathrm{C}$ for $12-15 \mathrm{~min}$. after baking biscuits were allowed to cool at room temperature for $1 \mathrm{hr}$. before organoleptic evaluation. 
Nahed, M.M. Atta et al

Table (1):

The formula of biscuit preparation(g)

\begin{tabular}{|c|c|c|c|c|c|}
\hline \multirow{2}{*}{ Ingredients } & \multirow{2}{*}{ Control biscuits } & \multicolumn{2}{|c|}{ Bottle gourd seed biscuits } & \multicolumn{2}{|c|}{ Pumpkin seed biscuits } \\
\hline & & Oil BSOB & Powder BSPB & Oil PSOB & Powder PSPB \\
\hline Soft wheat flour & 56.82 & 56.82 & 43.08 & 56.82 & 43.59 \\
\hline BG Powder & - & - & 25.1 & - & - \\
\hline Pumpkin seed Powder & - & - & - & - & 24.59 \\
\hline Sugar & 17.05 & 17.05 & 17.05 & 17.05 & 17.05 \\
\hline Corn oil & 11.36 & - & - & - & - \\
\hline Bottle gourd seed oil & - & 11.36 & - & - & - \\
\hline Pumpkin seed oil & - & - & - & 11.36 & - \\
\hline Baking powder & 0.57 & 0.57 & 0.57 & 0.57 & 0.57 \\
\hline Fresh egg & 13.64 & 13.64 & 13.64 & 13.64 & 13.64 \\
\hline Vanilla & 0.57 & 0.57 & 0.57 & 0.57 & 0.57 \\
\hline Total & 100 & 100 & 100 & 100 & 100 \\
\hline
\end{tabular}

BSOB:Bottle gourd seed oil biscuitBSPB:Bottle gourd seed powder biscuitPSOB:Pumpkin seed oil biscuit

PSPB: Pumpkin seed powder biscuit

\section{Sensory evaluation of biscuits:}

Produced biscuits by using suggested blends were evaluated for their sensory characteristics by ten panelists from the staff of Bread and Pastry Research Dept, FTRI, Agric. Res. Center. Giza, Egypt. The scoring scheme was established as mentioned by Thanaa Amer (2000) as follows: color of crust (20), taste(20), odor(20), crunchiness (20), appearance (20), and overall score 100 degrees.

\section{Physical properties of biscuit}

Samples of biscuits from each groups were taken to determine average diameter $(\mathrm{cm})$, thickness, $(\mathrm{cm})$, expansion factor $(\mathrm{o} / \mathrm{t}) \mathrm{cm} 3 / \mathrm{gm}$, volume $(\mathrm{cm} 3)$ and weight $(\mathrm{gm})$.

\section{Extraction of oil from biscuit}

The biscuit samples were cut into small particles and soaked in $\mathrm{n}$-hexan for $24 \mathrm{hrs}$ then the miscellanea was collected and filtered, this process was repeated three times using fresh solvent each time. Solvents were distilled the miscellanea on a water path and the last traces of the solvent were removed by distillation under vacuum at $40^{\circ} \mathrm{C}$. The obtained extracted oil samples were stored in dark bottles at $5^{\circ} \mathrm{C}$ until analysis.

\section{Chemical composition of seeds}

Chemical composition of bottle gourd and pumpkin seeds:-moisture, oil contents (in whole and dehulled seeds)protein, ash, total carbohydrates, fiber and minerals were determined according to the methods of A.O.A.C (2000).

\section{Physical and chemical characteristicsof oils:}

Refractive Index of oils, were determined at $25^{\circ} \mathrm{C}$ according to A.O.A.C (2000) by using refractometer (NXRL -3 Poland).Free fatty acids (\%) and peroxide values (Meq.O2/Kg oil) were determined according to the methods of the A.O.C.S (2005). lodine and saponification values: calculated from fatty acids percentages by equation according to Susana (1995). Absorbency in ultraviolet 232 and $270 \mathrm{~nm}$ Ultraviolet and visible spectra were conducted using a pyeunicum double beam recording spectrophotometer model SP 1600, as described by Kates (1972). The oil samples were dissolved in freshly distilled cyclohexane and the absorption was measured at 232 and $270 \mathrm{~nm}$.

Determination of stability of oils: Stability of the oils was determined according to the method of Mendzet al., (1997). 


\section{Egypt. J. of Nutrition and Health Vol. 15 No. 1 January (2020)}

Determination of fatty acids composition: The fatty acids methyl ester were prepared using transestrification with cold methanolic solution of potassium hydroxide. The fatty acids methyl esters were identified by GS- Capillary column according to the method of IOOC (2001).

Determination of some bioactive compounds in oil samples:

Total polyphenols was determined according to the method of Gutfinger (1981). Alphatocopherol was determined according to the method described by Wong et al., (1988). The chlorophyll of oil samples was determined according to the method of Mosquera et al., (1991), while the B- Carotene as described by Pupin et al., (1999).

\section{Determination of amino acids in biscuit}

The amino acids profile was determined according to the method described by Cohen et al., (1989) using HPLC device.

The total antioxidant activity was determined by using DPPH radical assay method (Okawaet al., 2001). The percentage scavenging inhibition (SI) of the test samples was calculated as:\% scavenging inhibition $(\mathrm{SI})=[($ Absorbance of DPPH blank-Absorbance of sample)/Absorbance of DPPH blank $] \times 100$

\section{Statistical Analysis}

The data obtained from sensory evaluation and other analysis were statistically analyzed by the least significant differences (L.S.D) at the levels $(p<0.05)$ probability procedures of Snedecor and Cochram (1990).

\section{Results and discussion}

\section{Chemical composition of seeds}

The chemical composition of bottle gourd and pumpkin whole seeds was given in Table (2). As considered in this table there were differences observed between the two seeds in their contents of oil, protein, crude fiber, total carbohydrate and ash. The results indicated that, both the whole seeds contained high amounts of crude oil, crude fibers followed by total carbohydrates then total protein and moisture content. The results also revealed that, the pumpkin seeds had moisture, crude oil, protein and ash contents higher than that in bottle gourd seeds, vice versa for total carbohydrates and crude fibers. Finally, it could be concluded that bottle gourd and pumpkin seeds are considered a good source of protein. Beside that, both the two seeds are good source of edible oil.

Table (2):

Chemical composition of seeds (\%).

\begin{tabular}{|c|c|c|c|c|c|c|}
\hline \multirow{2}{*}{ Seeds } & \multicolumn{6}{|c|}{ Chemical Composition (\%) } \\
\hline & Moisture & Oil & T. Protein & T. Carbohydrates & Ash & Fiber \\
\hline Bottle gourd & 5.8 & 31.42 & 10.75 & 17.70 & 2.6 & 31.73 \\
\hline Pumpkin & 6.77 & 39.51 & 13.56 & 16.01 & 2.8 & 21.35 \\
\hline
\end{tabular}

\section{Chemical composition of defatted meals}

Regarding to the chemical composition of defatted meals of bottle gourd and pumpkin seeds (Table 3) crude fiber was the highest constituent in both the two defatted meals followed by total carbohydrates, then crude protein and ash. Results in Table 3 also indicated that, defatted meal of bottle gourd seed has crude fiber higher than that of defatted meal of pumpkin seed. While the other contents were higher in defatted meal of pumpkin seed compared with defatted meal of bottle gourd seed. 


\section{Egypt. J. of Nutrition and Health Vol. 15 No. 1 January (2020)}

Corn oil had good quality as evidenced by its initial peroxide value $(0.66 \mathrm{meq}$. O2/kg oil) and acidity $(0.13 \%)$. Furthermore, the diene and triene (K232 and $270 \mathrm{~nm}$.) of corn oil were found to be 0.76 and $0.19 \mathrm{~nm}$. respectively, which are below the average range for vegetable oils. Also the stability of this oil was found to be $21.71 \mathrm{hr}$ that indicating the good quality of corn oil used in biscuit preparation. Also, the corn oil was rich in omega 6 and 9 fatty acids $(C 18: 2=55.87 \%$ and $C 18: 1=29.61 \%)$ proofing the health properties of corn oil.

As shown in Table 5, there were high significant differences between studied oils in color units (red, blue and yellow). The higher values of color of PSO than BSO is related to higher amount of pigment in POS than that in BSO under study. But refractive index (R.I) for each oil at $25^{\circ} \mathrm{C}$ was similar and indicates high degree of purity of both oils (Popoola et al., 2016). The obtained values of the acidity, peroxide value, iodine value and oxidative stability of BSO were significantly different compared with values of PSO. While,there were no significant difference observed for the values of K230, K270 $\mathrm{nm}$ and saponification value for these oils. The low amounts of acidity and peroxide value for previous oils make them agreeable as edible oil; also the low peroxide value for both oils indicates its high oxidative stability.lodine value (IV) demonstrates the levels of unsaturation and potential oxidative sensitivities of the oils. The high values of I.Vof these oils may be due to the high level of unsaturated fatty acids. BSO and PSO have the same values from saponification value. This indicates that both oils have similar molecular weight. This property of these oils depends on the presence of higher fatty acids and its high saturation level. High saponification values of BSO and PSO indicates that it is suitable for use in industry (Allam, 2010). Also results in Table (5) indicated that oil from bottle gourd seeds had higher oxidative stability than oil from pumpkin seeds. The BSO is more stable against oxidation because of its high content of $\alpha$ tocopherol and polyphenols as shown in Table 6.

\section{Bioactive components of seed oils:-}

The values of some bioactive components (total polyphenols, $\boldsymbol{\alpha}$-tocopherol, chlorophyll and carotenoids contents) of BSO and PSO showed statistical variation, as shown in Table (6). BSO had a higher content of $\boldsymbol{\alpha}$-tocopherol than PSO. On the contrary PSO had higher amount of total polyphenols, chlorophyll and carotenoids in comparison with BSO. As a rule BSO and PSO are rich in natural antioxidants, which support their use for nutrition.

Table (6):

Bioactive components of seed oils (ppm.).

\begin{tabular}{l|c|c|c|c}
\hline Bioactive Components & T. Polyphenols & a. Tocopherols & Chlorophyll contents & Carotenoid contents \\
\hline Bottle gourd & $71.17 \pm 0.44^{\mathrm{b}}$ & $38.53 \pm 1.2^{\mathrm{a}}$ & $0.78 \pm 0.003^{\mathrm{b}}$ & $0.57 \pm 0.006^{\mathrm{b}}$ \\
\hline Pumpkin & $78.33 \pm 0.61^{\mathrm{a}}$ & $6.23 \pm 1.6^{\mathrm{b}}$ & $1.31 \pm 0.02^{\mathrm{a}}$ & $4.05 \pm 0.003^{\mathrm{a}}$ \\
\hline
\end{tabular}

\section{Fatty acid composition of seeds oil.}

The fatty acid composition of BSO and PSO consisted of twelve fatty acids for the two varieties as shown in Table 7 It shows variations in their contents of fatty acids, variation in total saturated fatty acids, (TSFA), total unsaturated fatty acids (TUSFA), monounsaturated fatty acids (MUSFA), polyunsaturated fatty acids (PUSFA) and ratios of TUSFA/TSFA, C18:1/C18:2 and MUSFA/PUSFA. The main saturated fatty acids in BSO and PSO were palmitic acid followed by stearic acid. Both oils contained similar high amounts of TUSFA. The major MUSFA for BSO and PSO was oleic acid C18:1. Also, from the data presented in Table (7), both BSO and PSO are rich in linoleic acid (C18:2) as omega 6 fatty acid. 


\section{Nahed, M.M. Atta et al}

Moreover, the ratios of C18:1/ C18:2 and MUSFA/PUSFA are important parameters for oils stability in highly unsaturated oils. Concerning the ratio of MUSFA/PUSFA, it was different in the two studied oils. This ratio indicated that, the studied oils had high content of PUSFA, which may make it attractive for consumers who wish to use this type of oil.

Table (7):

Fatty acids composition of seeds oil (\%).

\begin{tabular}{|c|c|c|c|}
\hline $\begin{array}{ll}\text { Fatty acids composition } & \text { Oils } \\
\end{array}$ & $\mathrm{CO}$ & BSO & PSO \\
\hline $\mathrm{C} 14: 0$ & 0.06 & 0.15 & 0.20 \\
\hline C16:0 & 9.66 & 14.02 & 12.79 \\
\hline C16:1 & 0.12 & 0.08 & 0.15 \\
\hline $\mathrm{C} 17: 0$ & 0.08 & 0.10 & 0.21 \\
\hline C17:1 & 0.04 & 0.02 & 0.09 \\
\hline C18:0 & 2.54 & 6.65 & 6.66 \\
\hline C18:1 (w 9) & 29.61 & 16.79 & 27.62 \\
\hline C18:2 ( $(\omega 6)$ & 55.87 & 61.24 & 51.29 \\
\hline C18:3 ( $(\omega 3)$ & 1.04 & 0.31 & 0.21 \\
\hline $\mathrm{C} 20: 0$ & 0.39 & 0.37 & 0.52 \\
\hline C20:1 & 0.27 & 0.16 & 0.12 \\
\hline $\mathrm{C} 22: 0$ & 0.35 & 0.11 & 0.14 \\
\hline Total saturated fatty acids (TSFA) & 13.08 & 21.40 & 20.52 \\
\hline Total unsaturated fatty acids (TUSFA) & 86.95 & 78.60 & 79.48 \\
\hline TUSFA/ TSFA & 6.64 & 3.67 & 3.87 \\
\hline C18:1/ C18:2 & 0.52 & 0.27 & 0.54 \\
\hline MUSFA & 30.04 & 17.05 & 27.98 \\
\hline PUSFA & 56.91 & 61.55 & 51.50 \\
\hline MUSFA/ PUSFA & 0.53 & 0.28 & 0.54 \\
\hline C18:2/ C16:0 & 5.78 & 4.37 & 4.01 \\
\hline
\end{tabular}

Fatty acid composition of extracted oils:-

Table ( 8 ) gives the changes in the fatty acids composition of the extracted oils from biscuit $\mathrm{CO}, \mathrm{BSO}$, BSP, PSP and PSO and compared with fatty acids composition of the same fresh oils before baking process as shown in previous Table(7)The values of C18:2 and C18:3, while C16:0, C18:0 and C18:1 increased by baking process Table (8) compared with those in Table(7), there fore, there was decrement in TUSFA/TSFA ratio and increment C18:1/C18:2 ratio by baking process. The decrease in unsaturated fatty acids $\mathrm{C} 18: 2$ and $\mathrm{C} 18: 3$ was mainly due to the oxidation of unsaturated fatty acid into primary and secondary oxidation products, which decrease the percentage of TPUFA by temperature of baking process, where as the increase saturated fatty acids (C16:0 and $C 18: 0)$ and $C 18: 1$ relatively occurred as a result of the decrease in C18:2 and C18:3. Also the TSFA in all extracted oils were increased as a result of baking process due to decrease in total unsaturated fatty acids (relative increase). The ratio of $\mathrm{C} 18: 2 / \mathrm{C} 16: 0$ is usually used as indicator of the extent of fat deterioration because C18:2 is more susceptible to oxidations (Plessis et al,1981). It is clear from the results, the ratio (C18:2/ C16:0) decreased as a result baking process. This decrease is due to increase of $\mathrm{C} 16: 0$ and decrease in C18:2 as a result of baking process (under study). 
Egypt. J. of Nutrition and Health Vol. 15 No. 1 January (2020)

Table (8):

Fatty acid composition of biscuits.

\begin{tabular}{|c|c|c|c|c|c|}
\hline \multirow[b]{2}{*}{ Fatty acids composition of biscuits (\%) } & \multicolumn{5}{|c|}{ Extracted oils from biscuit made from } \\
\hline & Corn Oil (CO) & $\begin{array}{l}\text { Bottle gourd seed } \\
\text { oil (BSO) }\end{array}$ & $\begin{array}{c}\text { Bottle gourd seed } \\
\text { powder (BSP) }\end{array}$ & $\begin{array}{l}\text { Pumpkin seed oil } \\
\text { (PSO) }\end{array}$ & $\begin{array}{l}\text { Pumpkin seed } \\
\text { powder (PSP) }\end{array}$ \\
\hline C14:0 & 0.44 & 0.19 & 0.22 & 0.24 & 0.26 \\
\hline C16:0 & 12.26 & 14.91 & 14.88 & 13.96 & 15.12 \\
\hline $\mathrm{C} 16: 1$ & 0.55 & 0.36 & 0.36 & 0.51 & 0.54 \\
\hline $\mathrm{C} 17: 0$ & 0.82 & 0.11 & 0.62 & 0.36 & 0.20 \\
\hline C17:1 & 1.87 & 0.03 & 0.34 & 0.43 & 0.39 \\
\hline C18:0 & 3.20 & 6.85 & 7.53 & 6.83 & 6.86 \\
\hline C18:1(w9) & 29.67 & 18.02 & 18.44 & 27.90 & 29.26 \\
\hline C18:2 (w 6) & 47.45 & 58.63 & 56.71 & 49.00 & 46.62 \\
\hline C18:3 (w 3) & 1.16 & 0.28 & 0.19 & 0.13 & 0.12 \\
\hline $\mathrm{C} 20: 0$ & 0.88 & 0.31 & 0.31 & 0.31 & 0.23 \\
\hline $\mathrm{C} 20: 1$ & 1.30 & 0.20 & 0.21 & 0.18 & 0.27 \\
\hline $\mathrm{C} 22: 0$ & 0.40 & 0.11 & 0.19 & 0.15 & 0.13 \\
\hline Total saturated fatty acids (TSFA) & 18.04 & 22.48 & 23.75 & 21.85 & 22.80 \\
\hline Total unsaturated fatty acids (TUSFA) & 82.02 & 77.52 & 76.25 & 78.15 & 77.20 \\
\hline TUSFA/ TSFA & 4.55 & 3.45 & 3.21 & 3.58 & 3.38 \\
\hline C18:1/ C18:2 & 0.58 & 0.31 & 0.32 & 0.56 & 0.62 \\
\hline MUSFA & 31.39 & 18.61 & 19.35 & 28.62 & 30.26 \\
\hline PUSFA & 50.61 & 58.91 & 56.90 & 49.53 & 46.94 \\
\hline MUSFA/ PUSFA & 0.62 & 0.31 & 0.34 & 0.58 & 0.64 \\
\hline C18:2/ C16:0 & 3.87 & 3.93 & 3.81 & 3.51 & 3.08 \\
\hline
\end{tabular}

\section{Chemical composition of biscuits.}

The chemical composition of prepared biscuit using BSO, BSP, PSO and PSP are compared with prepared biscuit using $\mathrm{CO}$ as control are presented in Table (9). The result indicated significant differences in T. protein, T. carbohydrates, oil, ash and crude fiber contents of fortified biscuits with BSO, BSP, PSO and PSP compared with produced biscuit using CO.Generally, biscuit made from corn oil has higher amounts of total carbohydrates, oil and ash, but has lower amount of total protein and crude fiber than other biscuits made from BSO, BSP, PSO and PSP. Data in this Table (9), protein content in fortified biscuit with PSP recorded higher increase followed by biscuit fortified with PSO then with BSP and with BSO, this due to seeds powder of bottle gourd and pumpkin which contain a considerable amount from protein content.

Table (9):

Chemical composition of produced biscuit (dry weight \%)

\begin{tabular}{l|c|c|c|c|c}
\hline \multicolumn{1}{r|}{ Ch. Composition } & protein & T. Carbohydrates & Oil & Ash & Crude fiber \\
\hline Biscuit type & 7.56 & 66.34 & 17.50 & 1.78 & 1.60 \\
\hline BSO biscuit & 8.38 & 63.34 & 14.00 & 1.26 & 1.73 \\
\hline BSP biscuit & 10.13 & 66.02 & 17.30 & 0.86 & 1.80 \\
\hline PSO biscuit & 12.81 & 63.21 & 14.20 & 1.04 & 1.70 \\
\hline PSP biscuit & 15.69 & 66.47 & 18.62 & 1.04 & 1.76 \\
\hline
\end{tabular}

Amino acids composition of biscuits :

Date in Table (10) shows the amino acids composition of prepared biscuits using CO, BSO, BSP, PSO and PSP. The amino acids (tryptophan, methionene, phenyl alanine, cystine, leucine, isoleucine, threonine, histidin,valine andarginine) were detected in all prepared biscuits. Prepared biscuits from PSP and BSP were rich in arginine, leucine, valine and phenyl alanine. While biscuit prepared from PSO and BSO were rich in isoleucine. It was clear that, the prepared biscuit from PSP, $\mathrm{BSP}, \mathrm{BSO}$ and PSO were rich in amino acids compared with those in prepared biscuit from CO. This may be attributed to pumpkin and bottle gourd seeds which are rich in protein and amino acid contents. 
Table (10) :

Amino acids composition of biscuit

\begin{tabular}{l|c|c|c|c|c}
\hline & & & & \\
Amino acid (mg/g) & COB & BSPB & PSPB & BSOB & PSOB \\
\hline Tryptophan & & & & & \\
\hline Methionene & 0.0064 & 0.5310 & 0.5230 & 0.0842 & 0.0048 \\
\hline Phenyl alanine & 0.0054 & 0.8110 & 0.9140 & 0.0866 & 0.0054 \\
\hline Cystine & 0.0084 & 1.6400 & 1.4200 & 0.5231 & 0.6451 \\
\hline Leucine & 0.0023 & 0.4010 & 0.2980 & 0.3240 & 0.5831 \\
\hline Isoleucine & 0.00258 & 3.0000 & 3.3520 & 0.0311 & 0.0518 \\
\hline Arginine & 0.0520 & 1.3390 & 1.3490 & 1.3880 & 1.8560 \\
\hline Threonine & 0.0855 & 4.1010 & 5.5840 & 0.5630 & 0.6042 \\
\hline Histidine & 0.00846 & 0.9320 & 0.8960 & 0.0661 & 0.0842 \\
\hline Valine & 0.0055 & 1.2840 & 0.8140 & 0.6771 & 0.0554 \\
\hline COB:Corn oil biscuit BSPB: Bottle gourd seed powder biscuit PSPB: Pumpkin seed powder biscuit & BSOB:Bottle \\
gourd seed oil biscuit PSOB:Pumpkin seed oil biscuit. & & & 0.0567 \\
\hline
\end{tabular}

Physical properties of biscuits: The values of moisture, diameter $(\mathrm{cm})$, thickness $(\mathrm{T})(\mathrm{cm})$, expansion $(\mathrm{D} / \mathrm{T})$, volume $(\mathrm{cm} 3)$, weight $(\mathrm{gm})$ and volume/weight $(\mathrm{cm} 3 / \mathrm{gm})$ ratio for produced biscuit showed statistical variation according to type of prepared biscuit (COB, BSOB, BSPB,PSOB and PSPB (Table 11). The moisture content, diameter, expansion factor decreased in prepared biscuits from BSO, BSP,PSO and PSP compared with that prepared from CO. On the contrary, thickness, volume and weight of produced biscuits made from previous oils increased compared with that prepared with $\mathrm{CO}$. Volume/ Weight (VN) ratio decreased in biscuit prepared from BSP and PSP, but it did not change in biscuit prepared from BSO and PSO.

Table (11):

Physical properties of prepared biscuits.

\begin{tabular}{l|c|c|c|c|c}
\hline \multicolumn{1}{r|}{ Prepared biscuit from } & COB & BSPB & PSPB & BSOB & PSOB \\
\hline Physical Properties & $3.91^{\mathrm{A}}$ & $2.10^{\mathrm{B}}$ & $2.80^{\mathrm{A}}$ & $3.52^{\mathrm{A}}$ & $3.66^{\mathrm{A}}$ \\
\hline Total moisture content \% & $2.90^{\mathrm{A}}$ & $2.40^{\mathrm{A}}$ & $2.90^{\mathrm{A}}$ & $2.20^{\mathrm{B}}$ & $2.80^{\mathrm{A}}$ \\
\hline Diameter "D" (cm) & $0.72^{\mathrm{A}}$ & $0.76^{\mathrm{A}}$ & $0.77^{\mathrm{A}}$ & $0.72^{\mathrm{A}}$ & $0.74^{\mathrm{A}}$ \\
\hline Thickness "T" (cm) & $4.03^{\mathrm{A}}$ & $3.15^{\mathrm{C}}$ & $3.52^{\mathrm{B}}$ & $3.96^{\mathrm{A}}$ & $3.64^{\mathrm{B}}$ \\
\hline Expansion factor D/T & $6.82^{\mathrm{A}}$ & $7.14^{\mathrm{A}}$ & $6.92^{\mathrm{A}}$ & $6.88^{\mathrm{A}}$ & $6.92^{\mathrm{A}}$ \\
\hline Volume (cm3) & $4.02^{\mathrm{A}}$ & $4.96^{\mathrm{A}}$ & $4.83^{\mathrm{A}}$ & $4.05^{\mathrm{A}}$ & $4.09^{\mathrm{A}}$ \\
\hline Weight (gm) & $1.69^{\mathrm{A}}$ & $1.44^{\mathrm{B}}$ & $1.43^{\mathrm{B}}$ & $1.69^{\mathrm{A}}$ & $1.69^{\mathrm{A}}$ \\
\hline V/W ratio (cm3/gm) & &
\end{tabular}

Means followed by the same superscript letter in the same rows are not significantly different $(p<0.05)$.

\section{Sensory evaluation of biscuit:}

Values of sensory evaluation (Taste, odor, color, text,appearance and total acceptance) of prepared biscuit from BSO, BSP,PSO, PSP and CO are shown in Table (12). From the tabulated results it could be observed that,the sensory evaluation were affected by the different additives of oil and powder of bottle gourd and pumpkin seeds compared with that of prepared biscuit by corn oil (CO). 


\section{Egypt. J. of Nutrition and Health Vol. 15 No. 1 January (2020)}

Table (12):

Sensory evaluation of biscuit:

\begin{tabular}{c|c|c|c|c|c|c}
\hline Sensory evaluation & Taste & Odor & Color & Texture & Appearance & Total Acceptance \\
\hline Prepared biscuit & $19 \pm 0.02^{\mathrm{B}}$ & $19 \pm 0.02^{\mathrm{A}}$ & $20 \pm 0.09^{\mathrm{A}}$ & $19 \pm 0.007^{\mathrm{B}}$ & $19 \pm 0.09^{\mathrm{B}}$ & $96 \pm 0.0009^{\mathrm{B}}$ \\
\hline COB & $19 \pm 0.002^{\mathrm{B}}$ & $18 \pm 0.05^{\mathrm{B}}$ & $20 \pm 0.4^{\mathrm{A}}$ & $19 \pm 0.09^{\mathrm{B}}$ & $19 \pm 0.7^{\mathrm{B}}$ & $95 \pm 0.08^{\mathrm{C}}$ \\
\hline BSPB & $20 \pm 0.002^{\mathrm{A}}$ & $19 \pm 0.06^{\mathrm{A}}$ & $18 \pm 0.8^{\mathrm{B}}$ & $20 \pm 0.06^{\mathrm{A}}$ & $20 \pm 0.08^{\mathrm{A}}$ & $97 \pm 0.008^{\mathrm{A}}$ \\
\hline PSPB & $19 \pm 0.02^{\mathrm{B}}$ & $19 \pm 0.08^{\mathrm{A}}$ & $18 \pm 0.6^{\mathrm{B}}$ & $19 \pm 0.34^{\mathrm{B}}$ & $18 \pm 0.09^{\mathrm{C}}$ & $93 \pm 0.02^{\mathrm{D}}$ \\
\hline BSOB & $18 \pm 0.02^{\mathrm{C}}$ & $18 \pm 0.002^{\mathrm{B}}$ & $18 \pm 0.9^{\mathrm{B}}$ & $16 \pm 0.98^{\mathrm{C}}$ & $16 \pm 0.09^{\mathrm{C}}$ & $88 \pm 0.06^{\mathrm{E}}$ \\
\hline PSOB & \multicolumn{7}{c}{ column are not significantly different $(p<0.05 \pm S E)}$.
\end{tabular}

Generally, prepared biscuit from PSP had the highest acceptance value in sensory evaluation, followed by CO biscuit then BSP, BSO and PSO biscuits. These results reveals that, fortified biscuit by powder of bottle gourd and pumpkin seeds had sensory attributes similar to the CO biscuit (Control).

\section{Some antioxidant compounds of oils extracted from biscuits:}

Results in Table (13) show the effect of addition of BSO, BSP,PSO, PSP and CO as control to the prepared biscuits on the total phenol, total flavonoids and the antioxidant activity (DPPH \%) of extracted oils from previous biscuits. From the obtained results it could be noticed that, there are significant changes in their contents. The highest amount of total polyphenols of oils were 6.88 and $6.653 \mathrm{mg} / \mathrm{g}$ for extracted oils from biscuits made from PSO and BSO followed by biscuit made from BSP and PSP, while the lowest amount was observed in extracted oil from the prepared biscuit from CO $(4.26 \mathrm{mg} / \mathrm{g})$. The highest amount of phenol content of prepared biscuit using BSO and PSO is expected as amount of the total polyphenols in bottle gourd and pumpkin seeds oils was high relatively as shown in Table (6).

The highest amount of total flavonoids was $6.43 \mathrm{mg} / \mathrm{g}$ and antioxidant activity (DPPH) was $92 \%$ of BSPB, but the lowest amount was $2.48 \mathrm{mg} / \mathrm{g}$ and $41 \%$ respectively for prepared of biscuit using corn oil (CO). On the other hand, biscuit made using (BSO, PSO and PSP) contained a considerable amount of total flavonoids and antioxidant activity (DPPH).

Table (13):

Bioactive components and antioxidant activity of biscuits.

\begin{tabular}{l|c|c|c}
\hline Biscuits type & Total Phenols $(\mathrm{mg} / \mathrm{g})$ & Total Flavonoids $(\mathrm{mg} / \mathrm{g})$ & Antioxidant Activity (DPPH) \% \\
\hline COB & $4.36 \pm 0.11^{\mathrm{E}}$ & $2.48 \pm 0.08^{\mathrm{C}}$ & $41.00 \pm 0.51^{\mathrm{E}}$ \\
\hline BSPB & $5.48 \pm 0.941^{\mathrm{C}}$ & $6.430 \pm 4.20^{\mathrm{A}}$ & $92.00 \pm 0.56^{\mathrm{A}}$ \\
\hline PSPB & $4.85 \pm 0.201^{\mathrm{D}}$ & $3.51 \pm 0.361^{\mathrm{B}}$ & $69.00 \pm 0.344^{\mathrm{D}}$ \\
\hline BSOB & $6.653 \pm 0.36^{\mathrm{B}}$ & $3.70 \pm 0.14^{\mathrm{B}}$ & $77.00 \pm 4.20^{\mathrm{C}}$ \\
\hline PSOB & $6.88 \pm 0.328^{\mathrm{A}}$ & $3.7 .0 \pm 0.50^{\mathrm{B}}$ & $85.00 \pm 1.3^{\mathrm{B}}$ \\
\hline
\end{tabular}

Means followed by the same superscript letter in the same column are not significantly different $(p<0.05 \pm S E)$.

\section{Conclusion}

Bottle gourd and pumpkin seeds are good source of protein, amino acids, minerals and edible oil.Extracted oils from bottle gourd and pumpkin seeds are rich in omega 6 and 9 (C18:2 and C18:1) fatty acids and bioactive components.Fortified biscuits using oil and powder of bottle gourd and pumpkin seeds contained higher amounts of natural antioxidants and essential amino acids than those in biscuit made from corn oil (control). Prepared biscuit from pumpkin seed powder (PSP) has got the highest acceptance value in organoleptic test compared with other biscuits. 


\section{References}

Achu, M.B., Fokou,E.,Tchiégang,C.,Fotso,M., andTchouanguep, F.M. (2005).

Nutritive value of some Cucurbitaceae oilseeds from different regions in Cameroon.African Journal of Biotechnology, 4(11):1329-1334.

Ahmed S.and Ravi P S. (2017).

Pumpkin Seed Oil: An Alternative Medicine. International Journal of Pharmacognosy and Phytochemical Research, 9(2); 223-227.

Alaa El-Dain, S. M., Ashraf, M. Sh., Houssin, K.A., Mona, M.M Doweidar and Mohamed, S.I.S. (2008).

Sensory and biological evaluation of biscuits supplemented with black cumin (Nigella sativa L.) and its extracts. Egypt J. of Appl. Sci., 23(11B): 579-599.

Allam, S. S., 2010

Evaluation of bottle gourd seeds as potential source of edible oil with anticancer properties, $5^{\text {th }}$ Arab Mams.com. Food and Dairy Sci. Tech

A.O.A.C (2000):

Official method of analysis of the association of the official analytical chemist $17^{\text {th }} \mathrm{Ed}$., association of the official analytical chemist Washington, DC. USA.

A.O.C.S (2005):

Official and Tentative Methods for the American Oil Chemists Society, $8^{\text {th }} \mathrm{Ed}$. Published by the American Oil Chemist's Society, Champaign. U.S.A.

Chinyere C. G., Emmanuel I. A., Nwaukwa I. C. and Ugbogu A. E. (2009).

Nutritive Value of Lagenariasphaerica seed (wild bottle gourd) from south-eastern Nigeria. Pakistan Journal of Nutrition 8(3): 284-287.

Cohen, S.A., Mewyes, M. and Travim, T.L. (1989).

The Pico-Tag method A manual of advanced techniques for amino acid analysis. Millipore, Billerica.

Deli, S. Farah Masturah M., TajulAris Y. and WamNadiah, W.A(2011).

The effect of physical parameters of the screw press oil expeller on oil yield from Nigella sativa L. Seeds. International Food Research Journal 18(4): 1367-1373.

Deshpande, J.R., Mishra, M.R., Meghre, V.S., Wadodkar, S.G. and Dorle, A.K. (2007).

Free radical scavenging activity of lagenariasiceraria (Mol.) Standl. Fruit. Natural Products Radiance, 6(2):127-130.

FAO (1992).

Minor oil crops.Edible oils. M-17 ISBN 29-5-103128-2. 


\section{Egypt. J. of Nutrition and Health Vol. 15 No. 1 January (2020)}

\section{Gutfinger, T. (1981).}

Polyphenols in olive oils. J.A.O.C.S. 61(9):966-968.

Fokou E., Achu M. B. and Tchouanguep F. M. 2004.

Preliminary nutritional evaluation of five species of egusi seeds in Cameroon. African Journal of Food, Agriculture,I Nutrition and Development 4 (1). 1-11.

100C. (2001).

Method of analysis of International Olive Oil Council preparation of the fatty acids methyl esters from olive oil and olive pomace oil Co/T.20/Doc.No.24.

John T, Stavros L and Evangelos S. L. (1997).

Characterization of crude and purified pumpkin seed oil, Grasas y Aceites 48(5):267-272.

Kates, N. (1972).

Technique of lipidology. American Elsevier publishing Co. Inc. New York.

Mendz, E.; Sanhveza, J.; Speisky II., and Valenzvela, A. (1997):

Comparisons Oxidative Stability of Fish Oil. J.A.O.C.S, 74(3):331-332.

Mona, M. M. Doweidar and Amany, M. M. Basiuony (2004).

Production of biscuit by using untraditional oils. Egyptian J. of Nutrition, 1(1):113-130.

Mosquora, M.M.L.; Rejano, N.L.; gandule, R.B.; Sanchez, G.A and Garrido, F.J. (1991). Color pigment correlation in virgin olive oil. J.A.O.C.S., 68:332-336.

Ogunbusola, M. E.,Fagbemi, T. N., \&Osundahunsi, O. F. (2010).

Amino acid composition of Lagenariasiceraria seed flour and protein fractions. Journal of food science and technology, 47(6): 656-661.

Okawa, M.; Kinjo, J.; Nohara, T. and Ono, M. (2001).

DPPH (1,1-diphenyl-2-picrylhydrazyl) radical scavenging activity of flavonoids obtained from some medicinal plants, Biol. Pharm. Bull. 24: 1202- 1205.

Plessis, L.M., VonTwisk, P., Neikerk, P.J. and Steym, M. (1981).

Evaluation of peanut and cotton seed oils for deep frying. J. Amer. Oil Chem. Soc., 58:575578.

Popoola, Y. Y.,Akinoso, R., \&Raji, A. O. (2016). Optimization of oil extraction from giant bushel gourd seeds using response surface methodology. Food science \& nutrition, 4(5): 759-65.

Pupin, A. M.; Dennis, M.J. and Tolodo, M.C. F. (1999).

HPLC analysis of carotenoids in orange juice. Food Chem. 64:269-275.

Snedecor, O. W and Cochram, G. W (1990).

Statistical methods. $7^{\text {th }}$ Ed. The lowa state Univ. press, Ames, lowa, USA; 593p. 
Nahed, M.M. Atta et al

Susana Nelson (1995).

Food analysis, fat characterization (Oscar, A. Pike), chapter 14, second edition.

ThanaaAmer , A.A (2000),

Biochemical studies on some peanuts products. Ph.D. thesis, Dept. of Biochemist, Fac. of Agric Cairo Univ., Egypt.

Warra, A.A. ;Ukpanukpong, R. U., and Wawata, I.G. (2016).

Physico-chemical and GC-MS Analysis of Calabash (Lagenariasiceraria) Seed Oil. IJBCRR, 14(1): 1-7.

Welman M. (2005).

Lagenariasiceraria. Available : www.plantzafrica.com/plantklm/agensic.htm (Accessed 7/8/2016, 2005).

Wong, M. L. Timms, R. E. and Cioh, E.M. (1988).

Colorimetric determination of total tocopherols in palm oil, olein and stearin. JAOCS, 65 (2): 258-261.

Yetisir H, M. Sakar and. Serce, S (2008).

Collection and morphological characterization of Lagenaria siceraria germplasm from the Mediterranean region of Turkey. Genet Resour Crop Evol 55:1257-1266. 
Egypt. J. of Nutrition and Health Vol. 15 No. 1 January (2020)

إستخدام زيت و مسحوق بذور اليقطين و القرع فى انتاج بسكويت عالى القيمة الغذائية

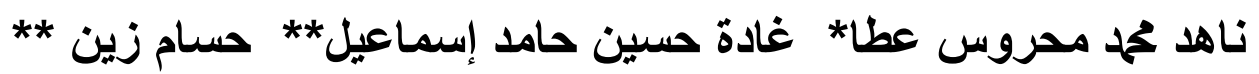

*قسم بحوث الزيوت والدهون **قسم بحوث الأغذية الخاصة والتغذية ـ معهد بحوث تكنولوجيا الاغذية

مركز البحوث الزراعية ـ الجيزة - مصر.

الملخص العربي

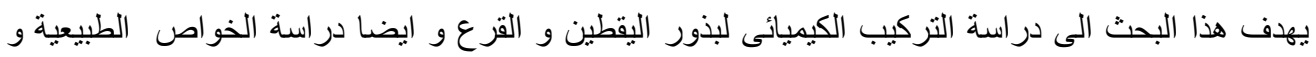

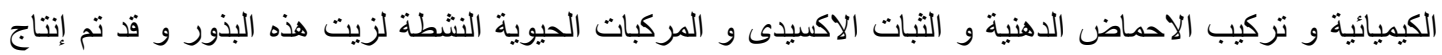

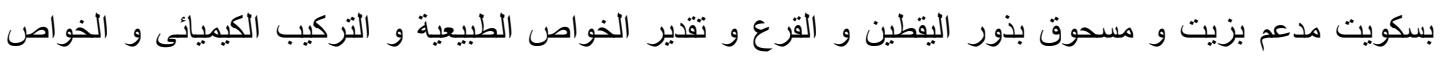
الحسية لهذا البسكويت المنتج و مقارنة ذللك بخواص البسكويت المصنع بإستخدام زيت الذرة (الكنترول - عينة

ضابطة).

وقد أشارت النتائج الى ان:-

كل من بذور اليقطين و القرع تعتبر مصدر غنى بزيت غذائى وكذلك البروتين و الالياف و العناصر المعدنية

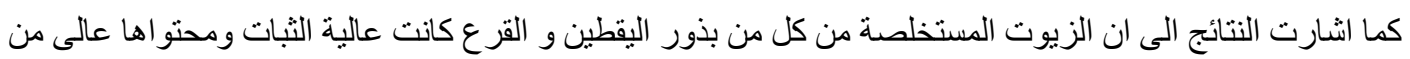

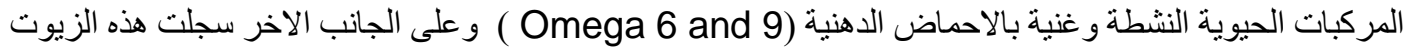

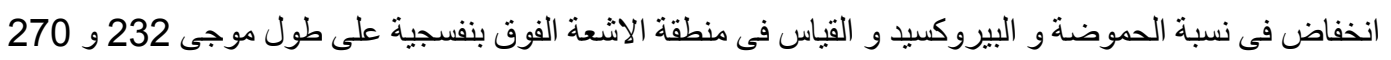
نانو ميتر و الذى يشير اعلى إرتفاع جودة خو اص هذه الزية الزيوت.

هناك نقص فى احماض اللينوليك و اللينولينيك و زيادة فى احماض البالمتيك و الاستيارك و الاوليك لجميع

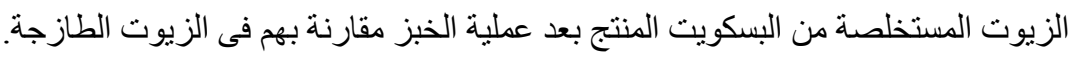

إحتو اء البسكويت الددعم بزيت و مسحوق بذور اليقطين و القرع على كمبة عالية من البروتين و الالياف و الاحماض الامينية الاساسية مقارنة بالبسكويت المصنع بإستخدام زيت الذرة.

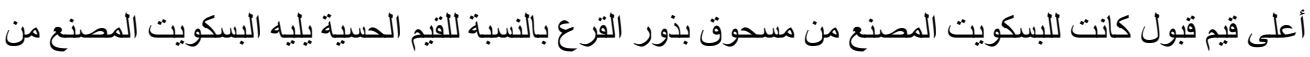

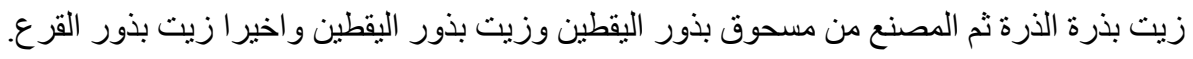

